\title{
HUBUNGAN KELEMBAPAN UDARA DAN CURAH HUJAN DENGAN KEJADIAN DEMAM BERDARAH DENGUE DI PUSKESMAS GUNUNG ANYAR 2010-2016
}

\author{
Ratna Maya Paramita, J. Mukono \\ Departemen Kesehatan Lingkungan, Fakultas Kesehatan Masyarakat \\ Universitas Airlangga Kampus C, Surabaya \\ Ratna Maya Paramita \\ Email: ratnamaya.paramita@gmail.com
}

\begin{abstract}
Dengue hemorrhagic fever is caused by dengue virus. The number of cases reported annually to World Health Organization ranged from 0,4 tol,3 million in the decade 1996-2005. The outbreak is annually happen on some provinces in Indonesia. The outbreak at 1998 and 2004 were the most cases in number. Surabaya city was an endemic area. It had suffered 640 people with 13 people were dead in 2015, which case fatality rate was 2,03\%. This study aims to analyze a correlation of humidity and rainfall with the incidence of dengue hemorrhagic fever at Gunung Anyar Primary Health Care, 2010-2016. The method of this research was time trend ecological study with the unit of analysis was per month during seven years. The results were showed that humidity correlated with dengue hemorrhagic fever ( $p=0.002$ and $r=+0.351$ ). So did the rainfall $(p=0.042$ and $r=+0.230)$. This research was concluded that humidity and rainfall correlated significantly with the incidence of dengue hemorrhagic fever. Sign of positive meant when humidity and rainfall increased, the incidence of dengue hemorrhagic fever increased too. Climate condition at Gunung Anyar district supports to make the incidence of dengue hemorrhagic fever happen. Because of that, people should improve their attention when peak seasons are coming, like doing mosquito breeding place elimination, keeping fish of mosquito larva predators, and using repellent among daily activities.
\end{abstract}

Keywords: dengue hemorrhagic fever, humidity, rainfall.

\begin{abstract}
ABSTRAK
Virus dengue adalah penyebab penyakit demam berdarah dengue. Jumlah rataan kasus yang dilaporkan kepada World Health Organization setiap tahunnya adalah 0,4 sampai 1,3 juta pada 19962005. Di Indonesia, setiap tahunnya selalu terjadi Kejadian Luar Biasa di beberapa provinsi, yang terbesar terjadi tahun 1998 dan 2004. Kota Surabaya sebagai daerah endemis DBD pada tahun 2015 terdapat 640 orang dan meninggal sejumlah 13 orang, yang berarti Case Fatality Rate mencapai 2,03 $\%$. Tujuan penelitian untuk menganalisis hubungan kelembapan dan curah hujan dengan kejadian demam berdarah dengue di Puskesmas Gunung Anyar, 2010-2016. Metode penelitian ini adalah studi ekologi menurut waktu dengan unit analisis per bulan selama tujuh tahun. Hasil penelitian menunjukkan bahwa kelembapan udara memiliki hubungan dengan kejadian demam berdarah dengue $(\mathrm{p}=0,002$ dan $\mathrm{r}=+0,351$ ). Sehingga didapatkan kesimpulan bahwa kelembapan dan curah hujan memiliki hubungan dengan DBD secara signifikan. Kemudian curah hujan juga memiliki hubungan dengan kejadian demam berdarah dengue $(\mathrm{p}=0,042$ dan $\mathrm{r}=+0,230)$. Kondisi iklim yang mendukung membuat masyarakat Gunung Anyar seharusnya meningkatkan kewaspadaan ketika musim puncak penularan penyakit dengan melakukan pengendalian vektor di lingkungan dan rumah, seperti kegiatan pemberantasan sarang nyamuk (PSN 3M) diiringi dengan memelihara ikan pemakan jentik dan penggunaan repellent saat beraktivitas.
\end{abstract}

Kata kunci: curah hujan, demam berdarah dengue, kelembapan. 


\section{PENDAHULUAN}

Kelembapan udara dan curah hujan merupakan bagian dari kondisi lingkungan fisik. Menurut Undang-Undang Nomor 32 tahun 2009 tentang perlindungan dan pengelolaan lingkungan hidup, menyatakan bahwa lingkungan hidup adalah kesatuan ruang dengan semua benda, daya, keadaan, dan makhluk hidup termasuk manusia dan perilakunya, yang memengaruhi perikehidupan dan kesejahteraan manusia serta makhluk hidup lain. Kemudian untuk Karakteristik lingkungan fisik adalah semua keadaan berbentuk fisik yang terdapat di sekitar manusia melakukan aktivitas yang dapat memberikan pengaruh. Salah satunya adalah faktor iklim (Gandahusada, dkk., 2006). Beberapa unsur yang memengaruhi iklim adalah curah hujan, kelembapan udara, suhu udara, tekanan udara, dan angin.

Menurut Intergovernmental Panel on Climate Change, Iklim dunia telah mengalami perubahan dengan cepat terutama karena gas rumah kaca antropogenik (IPCC, 2007). Gas rumah kaca antropogenik adalah penguatan efek rumah kaca melalui aktivitas manusia seperti penggunaan kendaraan bermotor yang meningkatkan kadar karbon dioksida di atmosfer bumi. Perubahan iklim dunia dapat memberikan pengaruh terhadap musim penularan dan area sebaran penyakit DBD di wilayah regional Asia-Pasifik. Hal tersebut berdasarkan studi literasi tentang hubungan perubahan iklim dengan DBD di beberapa negara, yaitu Thailand, Taiwan, India, Indonesia, China, Singapura, dan Australia (Banu, dkk., 2011).

Virus dengue adalah penyebab penyakit DBD. Jumlah rataan kasus yang dilaporkan ke World Health Organization setiap tahunnya adalah 0,4-1,3 juta pada 1996-2005. Kejadian Luar Biasa terjadi setiap tahun di beberapa provinsi di Indonesia, yang terbesar terjadi tahun 1998 dan 2004. Laporan pertama kali untuk penemuan penyakit Dengue di Indonesia adalah di Kota Jakarta dan Kota Surabaya pada tahun 1968. Kemudian pada tahun 2010 penyakit dengue tersebut telah menyebar di 440 Kabupaten/ Kota. Sejak ditemukan pertama kali kasus demam berdarah dengue terus mengalami peningkatan bahkan sejak tahun 2004 terjadi peningkatan kasus. Kenaikan tersebut berbanding terbalik dengan angka kematian atau case fatality rate (CFR) akibat DBD, dimana saat awal penemuannya dilaporkan bahwa CFR sekitar $40 \%$ selanjutnya terus turun di angka $0,87 \%$ pada tahun 2010 (Kemenkes RI., 2016).

Beberapa faktor yang berisiko terjadinya penularan dan semakin berkembangnya penyakit DBD adalah pertumbuhan jumlah penduduk yang tidak memiliki pola, faktor urbanisasi yang tidak berencana dan terkontrol, semakin majunya sistem transportasi sehingga mobilisasi penduduk sangat mudah, sistem pengelolaan limbah dan penyediaan air bersih yang tidak memadai, berkembangnya penyebaran dan kepadatan nyamuk, kurangnya sistem pengendalian nyamuk yang efektif, serta melemahnya struktur kesehatan masyarakat. Selain faktor lingkungan tersebut status imunologi seseorang, serotipe virus yang menginfeksi, usia dan riwayat genetik juga berpengaruh terhadap penularan penyakit. Perubahan iklim dunia sehingga memicu kenaikan suhu udara, perubahan pola musim hujan dan kemarau juga diperkirakan sebagai penyebab peningkatan risiko penularan DBD dan peningkatan risiko terkait kemunculannya (Kemenkes RI., 2015).

Penelitian di India menunjukkan bahwa perubahan iklim memiliki dampak terhadap transmisi dan kemunculan kembali penyakit yang menular melalui vektor (vector borne disease), seperti malaria, $\mathrm{DBD}$, dan chikungunya. Salah satu dampak perubahan iklim tersebut adalah peningkatan transmisi penyakit DBD akibat peningkatan suhu udara $\left(2^{0} \mathrm{C}\right)$ di bagian utara India (Ramesh, dkk., 2010). Kemudian salah satu efek tidak langsung antara perubahan iklim dan kesehatan masyarakat di Indonesia adalah terjadinya peningkatan suhu udara, curah hujan, kelembapan udara, dan kepadatan 
vektor dapat memiliki keterkaitan dengan peningkatan vector borne disease, seperti malaria, DBD, dan filariasis (Haryanto, 2009).

Angka kasus baru (incidence rate) penyakit DBD per 100.000 penduduk di Indonesia untuk tahun $2010(65,7)$, tahun $2011(27,8)$, tahun $2012(37,1)$, tahun 2013 (41,3), tahun $2014(39,8)$, dan tahun 2015 $(49,5)$ (Kemenkes RI, 2016). Penurunan tajam terjadi pada tahun 2010 ke 2011. Kemudian mengalami peningkatan hingga tahun 2013, tetapi sedikit menurun pada tahun 2014. Selanjutnya kembali meningkat pada tahun 2015.

Berdasarkan penelitian yang dilakukan di Kota Semarang pada periode tahun 20062011 untuk faktor iklim yang memiliki hubungan bermakna dengan arah positif terhadap kejadian DBD adalah curah hujan $(\mathrm{p}=0,001$ dan $\mathrm{r}=0,403)$ dan kelembapan udara $(p=0,001$ dan $r=0,533)$. Sehingga peningkatan curah hujan dan kelembapan udara diikuti juga dengan peningkatan kejadian DBD (Wirayoga, 2013). Kemudian berdasarkan penelitian di Kota Surabaya pada periode tahun 2010-2012 menunjukkan bahwa kelembapan udara memberikan efek terhadap angka bebas jentik (ABJ), tetapi ABJ tersebut tidak memiliki efek terhadap kasus DBD (Yudhastuti dan Notobroto, 2015).

Kota Surabaya sebagai daerah endemis demam berdarah dengue dengan jumlah kasus mencapai ratusan hingga ribuan dalam enam tahun terakhir dengan perinciannya adalah 1008 kasus pada 2011, 1301 kasus pada 2012, 2195 kasus pada 2013, 820 kasus pada 2014, 640 kasus pada 2015, dan 920 kasus pada 2016. Jumlah kasus DBD terendah yang terjadi di Kota Surabaya dalam enam tahun terakhir adalah pada tahun 2015. Terdapat pasien DBD sejumlah 640 orang dengan perincian penderita laki-laki sebanyak 263 orang dan penderita perempuan sebanyak 377 orang pada tahun 2015. Kemudian kasus meninggal pada pasien demam berdarah dengue tersebut sebanyak 13 orang, yang berarti CFR sebesar 2,03\%. Angka tersebut berada di atas target CFR di tingkat nasional, yaitu $\leq 1 \%$.

Kecamatan Gunung Anyar merupakan wilayah kerja dari Puskesmas Gunung Anyar. Jenis layanan yang diberikan dibagi menjadi empat. Jenis layanan tersebut adalah rawat jalan pagi (unit pelayanan umum, unit pelayanan gigi, unit pelayanan kesehatan ibu dan anak, unit pelayanan lansia, unit gizi, unit laboratorium, unit sanitasi), rawat jalan sore (unit pelayanan umum), rawat inap persalinan, dan pelayanan unggulan (Puskesmas santun lansia). Salah satu capaian prestasi yang membanggakan adalah berhasil memperoleh sertifikasi ISO 9001:2008 yang terkait dengan bidang sistem manajemen mutu. Keberhasilan tersebut menunjukkan bahwa Puskesmas Gunung Anyar sebagai instansi pemerintahan di bidang pelayanan kesehatan mampu memenuhi standard internasional dalam hal manajemen penjaminan mutu dari jasa pelayanan yang diberikan pihak Puskesmas kepada pengguna jasa.

Puskesmas Gunung Anyar sebagai lokasi penelitian adalah salah satu dari 62 Puskesmas yang menyebar di 31 kecamatan yang ada di Kota Surabaya. Wilayah kerja dari Puskesmas Gunung Anyar adalah seluruh daerah dalam Kecamatan Gunung Anyar dengan luasan 9,71 km². Kecamatan Gunung Anyar terletak di bagian timur Kota Surabaya yang berbatasan langsung dengan Kabupaten Sidoarjo di sebelah selatan dan Selat Madura di sebelah timur (Kecamatan Gunung Anyar dalam Angka, 2016).

Menurut data Dinas Kesehatan Kota Surabaya menunjukkan bahwa Puskesmas Gunung Anyar selalu mendapatkan kasus demam berdarah dengue minimal 20 penderita setiap tahunnya. Kasus demam berdarah dengue di Kecamatan Gunung Anyar mengalami peningkatan besar dari 20 kasus pada tahun 2014 menjadi 59 kasus pada tahun 2015. Peningkatan terjadi lebih dari 2 kali lipat (Dinkes Kota Surabaya, 2016). Hal tersebut membuat Kecamatan Gunung 
Anyar menjadi satu-satunya kecamatan di Kota Surabaya yang mengalami peningkatan kasus DBD hingga lebih dari 2 kali lipat. Kemudian terjadi peningkatan lagi menjadi 77 kasus pada tahun 2016 (Puskesmas Gunung Anyar, 2017). Sehingga penelitian terkait penyakit DBD perlu dilakukan di wilayah kerja Puskesmas Gunung Anyar.

Tujuan penelitian ini adalah untuk menganalisis hubungan kelembapan udara lingkungan dan curah hujan dengan kejadian DBD di Puskesmas Gunung Anyar Kota Surabaya dengan periode tahun 2010 sampai tahun 2016.

\section{METODE PENELITIAN}

Desain penelitian ini adalah studi ekologi. Studi ekologi memakai data agregat. Unit analisis penelitian ini adalah waktu per bulan selama tujuh tahun. Penelitian ini menggunakan data sekunder dari beberapa instansi terkait. Diantaranya adalah Puskesmas Gunung Anyar untuk mendapatkan data kasus DBD bulanan untuk tahun 2010-2016. Kemudian data kondisi iklim harian, berupa persentase kelembapan udara lingkungan dan curah hujan pada tahun 2010-2016 dari Badan Meteorologi, Klimatologi, dan Geofisika (BMKG) Stasiun Meteorologi Klas I Juanda. Berdasarkan data iklim harian tersebut, peneliti mengolahnya dahulu untuk dijadikan data bulanan. Variabel terikat atau dependen dari penelitian ini adalah kejadian demam berdarah dengue, kemudian untuk variabel bebas atau independen adalah kelembapan udara lingkungan dan curah hujan.

Analisis penelitian diawali secara univariat dengan penjelasan bahwa setiap variabel data dianalisis terkait distribusi frekuensinya. Hasil dari analisis univariat ini dapat disajikan dalam bentuk narasi, tabel, dan grafik. Kemudian untuk analisis bivariat adalah menguji dua variabel penelitian. Dua variabel penelitian tersebut adalah variabel bebas dan terikat. Analisis bivariat adalah dilakukan dengan menggunakan uji Korelasi Pearson untuk data yang berdistribusi normal. Bila salah satu data atau kedua data tersebut tidak berdistribusi normal maka digunakan uji alternatif, yaitu uji Korelasi Spearman. Sebelum melakukan uji korelasi, harus dilakukan uji One-Sample Kolgomorov Smirnov Test untuk mengetahui normalitas dari suatu distribusi data. Analisis penelitian ini disajikan dalam bentuk tabel, grafik, dan narasi sehingga dapat memperjelas hasil penelitian.

Kekuatan hubungan antara 2 variabel secara kualitatif dapat dibagi dalam 5 tingkatan (Dahlan, 2009), yaitu $(r=0,0$ 0,199 maka hubungan sangat lemah, $r=0,2$ 0,399 maka hubungan lemah, $r=0,4-0,599$ maka hubungan sedang, $r=0,6-0,799$ maka hubungan kuat, $r=0,8-1,00$ maka hubungan sangat kuat).

\section{HASIL \\ Distribusi Frekuensi Kejadian DBD}

Gambaran kejadian DBD per bulan yang telah terjadi dengan dinamis di wilayah kerja Puskesmas Gunung Anyar selama 7 tahun, yaitu mulai tahun 2010 sampai 2016. Kejadian DBD di Puskesmas Gunung Anyar tidak selalu ada di setiap bulan. Pada tahun 2011, terdapat enam bulan tanpa kasus DBD, yaitu bulan Januari, bulan Februari, bulan Juni, bulan Agustus, bulan November, dan bulan Desember. Sedangkan situasi tanpa kasus DBD pada tahun 2015 dan 2016, masing-masing hanya satu bulan. Kemudian untuk mengetahui distribusi frekuensi dari kejadian DBD per bulan di Puskesmas Gunung Anyar untuk tahun 2010-2016 dapat dilihat pada Tabel 1.

Tabel 1. Distribusi frekuensi kejadian DBD per bulan di Puskesmas Gunung Anyar, 2010-2016.

\begin{tabular}{lcccc}
\hline & $\begin{array}{c}\text { Standard } \\
\text { Deviation }\end{array}$ & Mean & Min & Max \\
\hline DBD & 5,0 & 4,3 & 1,0 & 20,0 \\
\hline
\end{tabular}

Distribusi frekuensi dari kejadian DBD per bulan di Puskesmas Gunung Anyar, 
tahun 2010-2016 menunjukkan jumlah terkecil adalah 1 kasus dan tertinggi adalah 20 kasus. Namun pernah tidak ada kasus DBD selama sebulan sepanjang tahun 20102016, tepatnya sekali tanpa kasus di tahun 2015 dan sekali tanpa kasus di tahun 2016. Kejadian DBD tertinggi tersebut terjadi pada bulan Januari, tahun 2010. Rataan kejadian DBD di Puskesmas Gunung Anyar setiap bulannya adalah 5 kasus.

\section{Distribusi Frekuensi Kelembapan Udara}

Gambaran kelembapan udara lingkungan per bulan yang telah terjadi dengan dinamis di wilayah kerja Puskesmas Gunung Anyar selama 7 tahun, yaitu mulai tahun 2010 sampai 2016. Kelembapan udara lingkungan di Puskesmas Gunung Anyar berdasarkan data sekunder dari BMKG Klas I Juanda menyatakan bahwa mayoritas berada pada angka $60 \%-80 \%$. Kemudian untuk mengetahui distribusi frekuensi dari kelembapan udara lingkungan di Puskesmas Gunung Anyar pada periode tahun mulai 2010 sampai 2016 dapat dilihat pada Tabel 2.

Tabel 2. Distribusi frekuensi kelembapan udara di Puskesmas Gunung Anyar, 2010-2016.

\begin{tabular}{lcccc}
\hline & $\begin{array}{c}\text { Standard } \\
\text { Deviation }\end{array}$ & Mean & Min & Max \\
\hline $\begin{array}{l}\text { Kelembapan } \\
\text { udara }\end{array}$ & 6,6 & 75,8 & 57,1 & 85,8 \\
\hline
\end{tabular}

Distribusi frekuensi dari kelembapan udara lingkungan per bulan di Puskesmas Gunung Anyar, tahun 2010-2016 menunjukkan persentase terkecil adalah $57,1 \%$ dan persentase terbesar adalah $85,8 \%$. Persentase kelembapan udara lingkungan tertinggi tersebut terjadi pada bulan September, tahun 2012. Kemudian untuk persentase kelembapan udara terendah terjadi pada bulan April, tahun 2010. Rataan kelembapan udara di Puskesmas Gunung Anyar setiap bulannya adalah $75,8 \%$.

\section{Distribusi Frekuensi Curah Hujan}

Gambaran kelembapan udara lingkungan per bulan yang telah terjadi dengan dinamis di wilayah kerja Puskesmas Gunung Anyar selama 7 tahun, yaitu mulai tahun 2010 sampai 2016. Curah hujan terjadi secara merata mulai dari bulan Januari sampai bulan Desember pada tahun 2010 dan tahun 2016. Pada tahun 2013 terjadi kekosongan data selama 6 bulan, mulai dari Januari hingga Juni akibat peralatan yang rusak sehingga tidak bisa mengirimkan hasil pengukuran kelembapan udara menuju server (pusat pengolahan data).

Tabel 3. Distribusi frekuensi curah hujan di Puskesmas Gunung Anyar, 20102016.

\begin{tabular}{ccccc}
\hline & $\begin{array}{c}\text { Standard } \\
\text { Deviation }\end{array}$ & Mean & Min & Max \\
\hline Curah hujan & 5,8 & 6,2 & 0,0 & 21,7 \\
\hline
\end{tabular}

Kemudian untuk mengetahui distribusi frekuensi dari curah hujan di Puskesmas Gunung Anyar untuk tahun 2010-2016 dapat dilihat pada Tabel 3.

Distribusi frekuensi dari curah hujan per bulan di Puskesmas Gunung Anyar, tahun 2010 sampai tahun 2016 menunjukkan angka terkecil adalah $0 \mathrm{~mm}$ dan angka terbesar adalah 21,7 mm. Angka curah hujan tertinggi tersebut terjadi pada bulan Maret, tahun 2012. Kemudian untuk angka curah hujan terendah terjadi beberapa kali di setiap tahun, kecuali pada tahun 2010, 2013, dan 2016. Karena pada tiga tahun tersebut curah hujan terjadi secara merata pada setiap bulan dengan kuantitas atau jumlah yang berbeda. Rataan curah hujan di Puskesmas Gunung Anyar setiap bulannya adalah $6,2 \mathrm{~mm}$.

\section{Hubungan Kelembapan Udara dengan Kejadian DBD}

Analisis bivariat menggunakan uji korelasi untuk mengetahui terkait ada atau tidaknya hubungan di antara 2 variabel yang diteliti. Uji korelasi juga dapat untuk 
mengetahui kekuatan hubungan antara dua variabel tersebut.

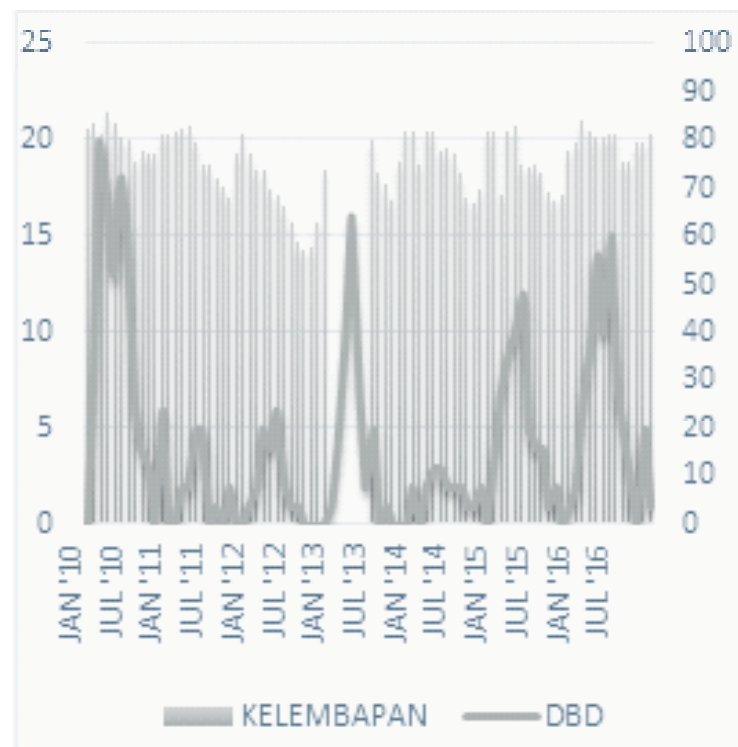

Gambar 1. Grafik Hubungan Kelembapan Udara Lingkungan dengan Kejadian DBD di Puskesmas Gunung Anyar, 2010-2016.

Variabel yang dianalisis dengan uji korelasi adalah antara DBD dengan kelembapan udara lingkungan dan DBD dengan curah hujan. Hubungan antara kelembapan udara dengan DBD dapat disajikan dalam bentuk grafik, seperti pada Gambar 1. Variabel DBD ditunjukkan dengan grafik garis dan variabel kelembapan udara dengan grafik batang.

Berdasarkan grafik tersebut menunjukkan bahwa fluktuasi antara kelembapan udara lingkungan dan kejadian DBD adalah kurang seirama. Sebelum melakukan uji hubungan antara kelembapan udara lingkungan dengan kejadian DBD sepanjang tahun 2010 sampai tahun 2016 adalah melakukan uji normalitas pada data menggunakan metode One-Sample Kolmogorov Smirnov Test.

Berdasarkan hasl uji dengan metode di atas menunjukkan hasil bahwa kejadian DBD per bulan berdistribusi tidak normal karena $\mathrm{p}=0,000$ tersebut lebih kecil dari 0,05 . Kemudian untuk data kelembapan udara menunjukkan hasil bahwa data tersebut berdistribusi normal karena $\mathrm{p}=0,152$. Setelah itu, uji hubungan antara kelembapan udara lingkungan dengan kejadian DBD di Puskesmas Gunung Anyar dapat dilakukan dengan menggunakan metode korelasi.

Tabel 4. Hasil analisis hubungan kelembapan udara lingkungan dengan kejadian DBD di Puskesmas Gunung Anyar, 20102016.

\begin{tabular}{lcc}
\hline \multirow{2}{*}{ Variabel } & \multicolumn{2}{c}{ Kejadian DBD } \\
\cline { 2 - 3 } & $\begin{array}{c}\text { Koefisien } \\
\text { korelasi }\end{array}$ & Signifikansi \\
\hline $\begin{array}{l}\text { Kelembapan } \\
\text { Udara }\end{array}$ & $+0,351$ & 0,002 \\
\hline
\end{tabular}

Hasil uji dengan metode Korelasi Spearman untuk hubungan antara persentase kelembapan udara lingkungan per bulan dengan kejadian demam berdarah dengue per bulan selama tahun 2010 sampai tahun 2016 dapat ditunjukkan dalam Tabel 4, seperti berikut.

Uji hubungan dilakukan dengan menggunakan metode Korelasi Spearman karena terdapat data yang berdistribusi tidak normal. Berdasarkan hasil uji Korelasi Spearman antara kelembapan udara lingkungan dengan kejadian DBD di Puskesmas Gunung Anyar mulai tahun 2010 sampai tahun 2016 adalah memiliki hubungan $(\mathrm{p}=0,002)$ dengan kekuatan hubungan yang lemah $(\mathrm{r}=0,351)$ dengan arah positif.

\section{Hubungan Curah Hujan dengan Kejadian DBD}

Uji korelasi antara curah hujan dengan kejadian DBD sepanjang tahun 2010 sampai tahun 2016. Namun, sebelum melakukan uji hubungan tersebut adalah melakukan uji normalitas pada data sekunder terkait kejadian DBD per bulan dari Puskesmas Gunung Anyar dan data sekunder terkait 
curah hujan per bulan dari Stasiun Meteorologi Klas I Juanda.

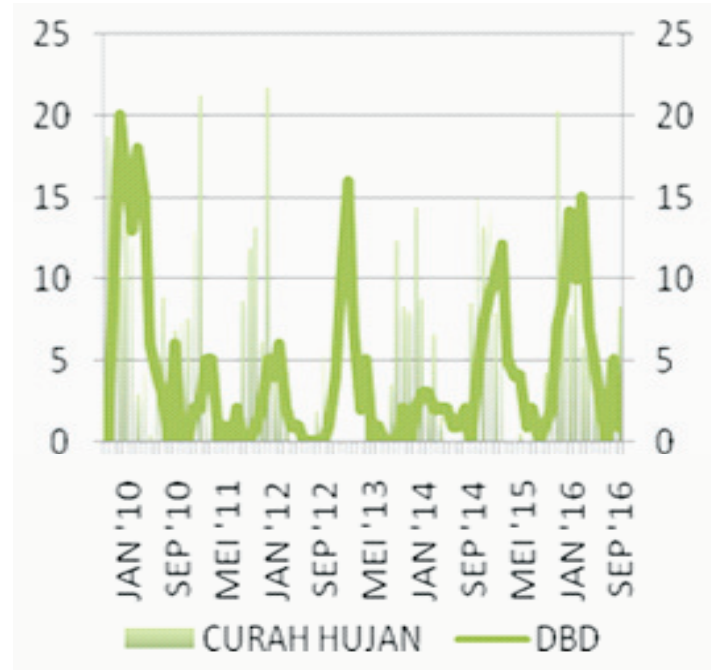

Gambar 2. Grafik Hubungan Curah Hujan dengan Kejadian DBD di Puskesmas Gunung Anyar, 2010-2016.

Uji normalitas menggunakan metode One-Sample Kolmogorov Smirnov Test menunjukkan hasil bahwa kejadian DBD per bulan berdistribusi tidak normal dengan $\mathrm{p}=0,000$.

Kemudian untuk data curah hujan menunjukkan hasil uji bahwa data tersebut berdistribusi normal dengan $\mathrm{p}=0,093$. Setelah itu uji hubungan antara curah hujan dengan kejadian DBD dapat dilakukan. Gambaran hubungan tersebut seperti yang tersaji dalam Gambar 2.

Grafik diatas menunjukkan bahwa fluktuasi antara grafik batang untuk variabel curah hujan dan grafik garis untuk variabel kejadian DBD kurang seirama. Uji hubungan dilakukan dengan menggunakan metode Korelasi. Metode tersebut adalah Korelasi Spearman. Hal tersebut dikarenakan terdapat satu variabel yang berdistribusi tidak normal, yaitu variabel kejadian demam berdarah dengue. Hasil uji dengan metode Korelasi Spearman untuk hubungan antara curah hujan per bulan dengan kejadian demam berdarah dengue per bulan selama tujuh tahun mulai dari tahun 2010 sampai tahun
2016 dapat dilihat dalam Tabel 5, seperti berikut.

Tabel 5. Hasil analisis hubungan curah hujan dengan kejadian DBD di Puskesmas Gunung Anyar, 20102016.

\begin{tabular}{ccc}
\hline \multirow{2}{*}{ Variabel } & \multicolumn{2}{c}{ Kejadian DBD } \\
\cline { 2 - 3 } & $\begin{array}{c}\text { Koefisien } \\
\text { korelasi }\end{array}$ & Signifikansi \\
\hline Curah hujan & $+0,230$ & 0,042 \\
\hline
\end{tabular}

Berdasarkan hasil uji Korelasi Spearman antara curah hujan dengan kejadian DBD di Puskesmas Gunung Anyar pada tahun 2010-2016 adalah memiliki hubungan $(\mathrm{p}=0,042)$ dengan kekuatan hubungan yang lemah $(\mathrm{r}=0,230)$ dengan arah positif.

\section{PEMBAHASAN}

\section{Hubungan Kelembapan Udara dengan Kejadian DBD}

Terdapat dua macam kelembapan udara yaitu kelembapan udara absolut dan kelembapan udara relatif. Kelembapan udara absolut, adalah banyaknya uap air yang terdapat di udara pada suatu tempat. Kemudian kelembapan udara relatif ialah perbandingan jumlah uap air dalam udara dengan jumlah uap air maksimum yang dapat dikandung oleh udara tersebut dalam suhu yang sama dan dinyatakan dalam persen. Terdapat uap air di udara yang berasal dari penguapan samudra sebagai sumber yang utama. Karena semakin tinggi suhu udara, makin banyak uap air yang dapat dikandungnya. Hal ini berarti udara menjadi lebih lembap. Alat untuk mengukur kelembapan udara dinamakan higrometer (Regariana, 2004).

Kondisi rerata kelembapan udara lingkungan per bulan di Puskesmas Gunung Anyar selama periode tahun 2010-2016 adalah $75,8 \%$. Kondisi kelembapan udara tersebut berada pada zona nyaman bagi nyamuk untuk berkembang biak. Ternyata tidak hanya 
mendukung kecepatan berkembang biak, kondisi lingkungan yang lembap dapat juga memengaruhi umur nyamuk, jarak terbang, dan kebiasaan menggigit (Cahyati, 2006). Oleh karena itu, kelembapan lingkungan rendah dapat mengakibatkan penguapan mengalami peningkatan yang merupakan hal yang menjadi musuh utama nyamuk.

Hasil penelitian menunjukkan bahwa variabel kelembapan udara per bulan memiliki hubungan dengan kejadian DBD per bulan di Puskesmas Gunung Anyar selama tahun 2010-2016. Hubungan tersebut diperoleh dari analisis dengan uji Korelasi Spearman dengan hasil nilai signifikansi (p) sebesar 0,002 . Nilai signifikansi yang lebih kecil dari 0,05 menunjukkan bahwa variabel bebas memiliki hubungan dengan variabel terikat. Kemudian dapat diketahui keeratan atau kekuatan hubungan tersebut dengan melihat nilai pada koefisien korelasi (r).

Kekuatan hubungan antara kelembapan udara lingkungan dengan kejadian DBD adalah lemah dengan nilai 0,351. Arah hubungannya adalah positif. Penjelasannya adalah semakin tinggi persentase kelembapan udara lingkungan di Kecamatan Gunung Anyar, maka kejadian DBD meningkat. Semua hasil analisis tersebut hanya berlaku untuk periode 7 tahun pada tahun 20102016 di wilayah kerja Puskesmas Gunung Anyar.

Hasil penelitian ini didukung dengan hasil penelitian lain yang sejenis, tetapi dilakukan di tingkat kota/ kabupaten yaitu Kota Semarang pada periode tahun 20062011. Penelitian tersebut menunjukkan bahwa kelembapan udara lingkungan memiliki hubungan dengan kejadian DBD, yakni $p=0,001$. Kemudian derajat kekuatan hubungannya sedang $(\mathrm{r}=0,533)$ dan arah hubungannya adalah positif (Wirayoga, 2013).

Penelitian lain juga menunjukkan bahwa kelembapan udara lingkungan memiliki hubungan dengan kejadian DBD. Salah satunya adalah penelitian yang dilakukan di Kecamatan Sangatta Utara
Kabupaten Kutai Timur (Kusumawati, 2012). Penelitian tersebut melakukan uji korelasi pada setiap tahunnya mulai dari tahun 2007 sampai tahun 2011. Kemudian diperoleh hasil bahwa kelembapan udara di lingkungan memiliki hubungan dengan DBD pada tahun 2007 dengan nilai korelasi (r) sebesar 0,939 dan memiliki arah hubungan yang negatif. Hubungan tersebut juga terjadi pada tahun 2009 dengan nilai korelasi (r) sebesar 0,853 dan memiliki arah hubungan yang negatif. Arah hubungan yang negatif menunjukkan hubungan yang bertolak belakang.

\section{Hubungan Curah Hujan dengan Kejadian DBD}

Hujan adalah peristiwa sampainya air dalam bentuk cair maupun padat yang dicurahkan dari atmosfer ke permukaan bumi. Curah hujan yaitu jumlah air hujan yang turun pada suatu daerah dalam waktu tertentu. Alat untuk mengukur banyaknya curah hujan disebut rain gauge. Curah hujan diukur dalam harian, bulanan, dan tahunan. Curah hujan yang jatuh di wilayah Indonesia dipengaruhi oleh faktor seperti, bentuk medan atau topografi, arah lereng medan, arah angin yang sejajar dengan garis pantai, jarak perjalanan angin di atas medan datar (Regariana, 2004).

Kondisi rerata curah hujan per bulan di Puskesmas Gunung Anyar selama periode tahun 2010-2016 adalah 6,2 mm. Setiap milimeter $(\mathrm{mm})$ dalam satuan tersebut dimaksudkan dengan perhitungan $(1 \mathrm{~mm}$ x $1 \mathrm{~m} \times 1 \mathrm{~m}$ ), sehingga dihasilkan volume curah hujan per meter persegi adalah satu liter. Kondisi curah hujan jelas memengaruhi kehidupan nyamuk, utamanya terkait dengan dapat meningkatkan tempat perindukan. Kemudian menurut Suroso (2000), curah hujan dapat menambah kepadatan nyamuk. Seperti setiap milimeternya dapat menambah kepadatan nyamuk sejumlah 1 ekor. Namun jumlah curah hujan mencapai $140 \mathrm{~mm}$ dalam seminggu maka larva hanyut kemudian mati. 
Hasil penelitian menunjukkan bahwa variabel curah hujan per bulan memiliki hubungan dengan kejadian DBD per bulan di Puskesmas Gunung Anyar selama tahun 2010-2016. Hubungan tersebut diperoleh dari analisis dengan uji Korelasi Spearman dengan hasil nilai signifikansi (p) sebesar 0,042 . Nilai signifikansi yang lebih kecil dari 0,05 menunjukkan bahwa variabel bebas memiliki hubungan dengan variabel terikat. Kemudian dapat diketahui keeratan atau kekuatan hubungan tersebut dengan melihat nilai pada koefisien korelasi (r).

Kekuatan hubungan antara curah hujan dengan kejadian DBD adalah lemah dengan nilai 0,230 . Arah hubungannya adalah positif. Penjelasannya adalah semakin tinggi jumlah curah hujan di Kecamatan Gunung Anyar, maka kejadian DBD meningkat. Semua hasil analisis tersebut hanya berlaku untuk periode 7 tahun pada tahun 2010-2016 di wilayah kerja Puskesmas Gunung Anyar.

Hasil penelitian ini didukung dengan hasil penelitian lain yang sejenis, tetapi dilakukan di Puskesmas Putat Jaya, Kota Surabaya pada periode 2010-2014 (Kurniawati, 2016). Penelitian tersebut menunjukkan bahwa curah hujan memiliki hubungan dengan kejadian DBD. Kemudian derajat kekuatan hubungannya lemah $(\mathrm{r}=0,141)$ dan arah hubungannya adalah positif.

Penelitian lain juga menunjukkan bahwa curah hujan memiliki hubungan dengan kejadian DBD, tanpa mengetahui kekuatan hubungannya. Diantaranya adalah penelitian yang dilakukan di Kabupaten Pacitan (Wulandari, 2016) dengan nilai signifikansi (p) sebesar 0,001. Selanjutnya adalah penelitian dari Kota Makassar (Rahim, dkk., 2016) yang menunjukkan bahwa faktor lingkungan, khususnya adalah curah hujan memiliki hubungan dengan tingkat endemisitas DBD. Hubungan tersebut menunjukkan nilai signifikansi (p) sebesar 0,000 . Serta penelitian yang dilakukan di Kota Semarang pada periode tahun 2006-2011. Faktor iklim yang memiliki hubungan bermakna dengan arah positif terhadap kejadian DBD adalah curah hujan $(\mathrm{p}=0,001$ dan $r=0,403$ ). Sehingga dapat disimpulkan bahwa peningkatan faktor iklim, berupa curah hujan dan kelembapan udara diikuti juga dengan peningkatan kejadian DBD di Kota Semarang (Wirayoga, 2013).

\section{SIMPULAN}

Kelembapan udara lingkungan memiliki hubungan $(p=0,002)$ terhadap kejadian DBD dengan kekuatan hubungan yang lemah $(r=0,351)$ yang menunjukkan arah positif. Kemudian curah hujan juga memiliki hubungan $(p=0,042)$ terhadap kejadian DBD dengan kekuatan hubungan yang lemah $(r=0,230)$ yang menunjukkan arah positif. Hubungan dengan arah positif tersebut memiliki makna bahwa semakin tinggi curah hujan dan persentase kelembapan udara lingkungan maka kejadian DBD menjadi semakin tinggi.

Sebaiknya puskesmas Gunung Anyar juga memberikan informasi terkait dengan kondisi iklim di Kecamatan Gunung Anyar yang mendukung terjadinya penyakit DBD sehingga dapat meningkatkan kesadaran dan kemauan masyarakat untuk melakukan penyehatan lingkungan di tempat tinggal mereka sendiri sebagai bentuk pengendalian vektor. Kemudian sebaiknya warga Kecamatan Gunung Anyar meningkatkan kewaspadaan saat musim pancaroba dari musim hujan ke musim kemarau karena waktu puncak penularan DBD di Kecamatan Gunung Anyar untuk tahun 2010 sampai tahun 2016 adalah pada bulan Maret, April, dan Mei. Kondisi lingkungan yang tergenang sisa air hujan dengan suhu udara lingkungan yang hangat pada musim pancaroba dapat mendukung kehidupan nyamuk Aedes Aegypti sebagai vektor penyakit DBD, seperti usia, tempat perindukan, dan perkembangbiakan.

Beberapa kegiatan kewaspadaan yang dapat dilakukan adalah dengan Pemberantasan Sarang Nyamuk (PSN 3M), diantaranya adalah menguras dan menyikat tempat penampungan air, menutup rapat 
tempat penampungan air, mendaur ulang barang bekas yang dapat menampung air hujan. Kemudian PSN 3M dapat diiringi dengan kegiatan plus lain, seperti memelihara ikan pemakan jentik, menghindari kebiasaan menggantung pakaian di kamar, memasang kawat kasa, menaburkan larvasida pada tempat yang sulit dikuras, dan penggunaan repellent selama beraktivitas (Kemenkes RI., 2015).

\section{DAFTAR PUSTAKA}

Banu, S., Hu, W., Hurst, C., dan Tong, S. 2011. Dengue Transmission in The Asia-Pacific Region: Impact of Climate Change and Socio-Environmental Factors. Tropical Medicine and International Health, Volume 16: pp 598-607. Tersedia di: http://www.ral.ucar.edu/staff/steinhoff/ Exp_summer2013/Papers/Dengue/Banu et_al_2011.pdf.

Cahyati, W dan Suharyo. 2006. Dinamika Aedes Aegypti Sebagai Vektor Penyakit. Jurnal Kesehatan Masyarakat, Volume 2 (No. 1). Tersedia di: https://www.scribd. com/doc/72150729/611-842-1-SM.

Dinkes Kota Surabaya. 2016. Profil Dinas Kesehatan Kota Surabaya Tahun 2015. Surabaya: Dinas Kesehatan Kota Surabaya. Tersedia di: http://www. depkes.go.id/resources/download/profil/ PROFIL_KAB_KOTA_2015/3578_ Jatim_Kota_Surabaya_2015.pdf.

Ditjen PP dan PL. 2010. Penemuan dan Tatalaksana Penderita Demam Berdarah Dengue. Jakarta: Direktorat Pengendalian Penyakit dan Penyehatan Lingkungan, Kementerian Kesehatan RI. Tersedia di: http://www.depkes.go.id/download. php? file=download/pusdatin/buletin/ buletin-dbd.pdf.

Gandahusada, Illahude, dan Pribadi. 2006. Parasitologi Kedokteran Edisi Ketiga. Jakarta: Universitas Indonesia.

Haryanto, B. 2009. Climate Change and Public Health in Indonesia, Impacts and Adaptation. Australia: Nautilus Institute at RMIT University. Tersedia di: http://nautilus.org/wp-content/ uploads/2012/02/haryanto1.pdf.

IPCC. 2007. Climate Change 2007: The Physical Science Basis: Contribution of Working Group I to the Fourth Assessment Report of the Intergovernmental Panel on Climate Change. Cambridge, United Kingdom: Cambridge University Press dan USA: New York.

Kecamatan Gunung Anyar dalam Angka. 2016. Kecamatan Gunung Anyar Dalam Angka 2016. Surabaya: Badan Pusat Statistika Kota Surabaya. Tersedia di: https://surabayakota.bps.go.id/website/ pdf_publikasi/Kecamatan-GunungAnyar-Dalam-Angka-2016.pdf.

Kemenkes RI. 2015. Pedoman Pengendalian Demam Berdarah Dengue di Indonesia. Jakarta: Kementerian Kesehatan Republik Indonesia.

Kemenkes RI. 2016. Infodatin 2016 (Situasi Demam Berdarah Dengue di Indonesia). Jakarta: Pengolahan Data dan Informasi, Kementerian Kesehatan Republik Indonesia. Tersedia di: http://www.depkes.go.id/ download.php?file=download/pusdatin/ infodatin/InfoDatin-2016-TB.pdf.

Kurniawati, N. 2016. Distribusi Kejadian Demam Berdarah Dengue, Kondisi Iklim, Kepadatan Jentik, dan Program Pengendalian di Wilayah Kerja Puskesmas Putat Jaya, Kota Surabaya Tahun 20102014. Skripsi. Surabaya: Universitas Airlangga.

Kusumawati, W. 2012. Adaptasi Demam Berdarah Dengue Hubungannya dengan Mitigasi Pemanasan Global dan Perubahan Iklim di Kecamatan Sangatta Utara, Kabupaten Kutai Timur, Provinsi Kalimantan Timur. Skripsi. Surabaya: Universitas Airlangga.

Puskesmas Gunung Anyar. 2017. Laporan Kasus Demam Berdarah Dengue. Surabaya: UPTD Puskesmas Gunung Anyar.

Rahim, S., Ishak, H., dan Wahid, I. 2016. Hubungan Faktor Lingkungan dengan Tingkat Endemisitas DBD di Kota 
Makassar. Tersedia di: https://researchgate. net/publication/273774233.

Ramesh, Pahwa, Dhillon, dan Dash. 2010. Climate Change and Threat of VectorBorne Diseases in India: Are We Prepared?. Parasitology Research, Volume 106: pp 763-773.

Regariana, M. 2004. Atmosfer (Cuaca dan Iklim). Solo: Tiga Serangkai. Tersedia di: https:// andimanwno.files.wordpress.com/2010/08/ atmosfer-cuaca-dan-iklim.pdf.

Republik Indonesia. 2009. UndangUndang Nomor 32 Tahun 2009 Tentang Perlindungan Dan Pengelolaan Lingkungan Hidup. Jakarta: Pemerintah Republik Indonesia.

Sopiyudin D. 2009. Statistik untuk Kedokteran dan Kesehatan. Jakarta: Salemba Merdeka.

Suroso, T. 2000. Penyakit Demam Berdarah dan Demam Berdarah Dengue. Jakarta: WHO dan Departemen Kesehatan RI.
Wirayoga, M. 2013. Hubungan Kejadian DBD dengan Iklim di Kota Semarang 2006-2011. Skripsi. Semarang: Universitas Negeri Semarang. Tersedia di:lib.unnes.ac.id/19377/1/6450407074. pdf.

Wulandari, R. 2016. Hubungan Sanitasi Lingkungan, Unsur Iklim, Keberadaan Jentik Nyamuk Aedes Aegypti terhadap Kejadian Demam Berdarah Dengue di Kabupaten Pacitan Tahun 2015. Skripsi. Surabaya: Universitas Airlangga.

Yudhastuti, R. dan Notobroto, H. 2015. Model of Controlling Dengue Hemorhhagic Fever Based on Climate Factors in Endemic Area (Surabaya City in 2010-2012). Bandung: 47th APACPH Conference. Tersedia di: http://apacph2015.fkm.ui.ac. $\mathrm{id} / \mathrm{ppt} / 21 \% 20$ October $\% 202015 / 9 . \% 20$ FP\%20Environmental\%20Health $\% 20$ C-Amartapura\%20C/7.\%20Ririh\%20 Yudhastuti.pdf. 